Collection Management, 2008, Vol. 33, No. 1-2, p.51-67.

ISSN: $1545-2549$ (paper) 0146-2679 (online)

doi: $10.1080 / 01462670802157940$

http://www.taylorandfrancis.com/

http://www.tandf.co.uk/journals/titles/01462679.asp

http://www.tandfonline.com/doi/abs/10.1080/01462670802157940

(C) 2008 The Haworth Press.

\title{
Managing Collections Between the Chemists and the Consortium: Assessment, Engagement, and Creativity
}

\author{
Celeste Feather \\ James K. Bracken \\ Jose Diaz
}

\begin{abstract}
Managing The Ohio State University Libraries' collection of chemistry journals within OhioLINK's consortial environment mixes objective assessment with engaging the chemistry faculty and the consortium. Basing collection decisions on hard facts has the immediate goal of cost-effectiveness. The most effective technique is a mediated three-party dialogue of the library managers, the chemistry faculty, and the consortium with the long-term goal of reforming scholarly communication. Many methods to assess electronic journals are available, such as article download statistics, impact factors, Eigenfactors, cost per article and cost per citation data, and engaging faculty input. The reality, however, is that high subscription costs do not diminish the importance of chemistry journals to the faculty. Assessment of consortial electronic journal subscription packages is crucial to managing collection content effectively, but library managers and chemistry faculty often disagree about the appropriate assessment method. The most effective approach is a combination of several assessment methods coupled with clear and open communication of the facts. Communicating the results of the assessment techniques is more than a matter of giving the faculty the bad news. The most effective and credible assessment methodology always includes communicating faculty input to the consortium. Difficult decisions are easier to make, announce, and live with when all stakeholders openly share information.
\end{abstract}

\section{INTRODUCTION}

In times defined by flat budgets and price inflation, one of the most responsible objectives of library managers is to try to change scholarly communication. This may sound like "tilting at windmills," but what are the alternatives? The reality is that without additional money to pay increased prices for content there is no "business as usual." It is hardly sustainable for libraries to rob all the possible Peters (the monographs budget, the equipment budget, the personnel budget, etc.) to pay Paul (the electronic serials budget) and thereby protect an eversmaller core of resources. Drawing ever-tightening rings around a core may buy time but it advances nothing, other than, perhaps, more price increases.

So what are library managers to do? At places like The Ohio State University Libraries, library managers finding themselves between a rock (the institution that allocates the flat budget) and hard places (publishers that increase their prices) can in fact devise solutions that distribute the discomfort. Herein "tilting at windmills" simply takes the perspective that scholarly communication is a process that has faculty producing, publishers publishing, and academic library managers buying (when their institutions are adequately allocating) for their faculty consumers. Crucial to sharing the pain inherent in trying to change scholarly communication is realigning faculty producers/consumers and library managers so that they are not separated by 
publishers. At the heart of the effort is education-of library managers, individually and consortially, and of faculty producers/consumers. Faculty that produce scholarly communication and library managers that buy the published product can cooperate in any number of ways to effectively exclude the middleman publisher or at least redefine or delimit the publisher's appropriate place. These other ways for faculty authors and library managers to cooperate and thereby alter the scholarly communication process (such as through institutional repositories or open access journals) are neither easy nor cheap. The fact remains that publishers add value to scholarly communication. Library managers and faculty producers/consumers who would replace publishers must pay a price to learn new skills. The question is, "What is the value of the publisher's role in scholarly communication?" In prolonged times of flat budgets, the library manager's answer is simply that any price increase is too much. Educating publishers is in fact a simple spelling lesson: "N-O." Educating faculty producers/consumers, on the other hand, is more complicated. "N-O" hardly goes down easy for either library managers or faculty. "Just get more money" is the nearly universal response.

Getting more money is not likely to happen, at least not in The Ohio State University Libraries, and herein follows one example of how some of its library managers have approached the situation with chemistry at Ohio State. These differences are especially sharp in the discipline of chemistry, which is well-known for expensive journal prices.

\section{PROBLEM STATEMENT}

As a member of the OhioLINK consortium, The Ohio State University Libraries benefits enormously from consortial purchases and subscriptions. Ohio State annually pays nearly three million dollars to OhioLINK for electronic resources. OhioLINK annually calculates how much of its state funding is spent to support electronic resources for each individual member institution, and Ohio State's calculated share of that state funding averages just over one million dollars annually. Basically, Ohio State receives a 33.3\% rate of return from OhioLINK's state capital funds for its investment in OhioLINK resources. The benefits of this relationship are clear. Ohio State can buy more consortially than it could ever afford to buy independently. Yet, as an increasing percentage of collection funds are bound in consortial deals, the flexibility to cancel journal titles in favor of more preferred ones is restricted. This becomes particularly apparent in times of flat budgets. Although there are certainly important common goals between the consortium and the research library, the approaches and values of the Libraries and their community of users differ from those of the consortium in significant ways, too.

The consortium is devoted to acquiring or leasing content that has broad appeal to member libraries in the most cost effective and efficient way possible. This strategy defines OhioLINK's success. No one can argue with those goals, but the big deal packages from publishers that bring thousands of electronic journals into the consortial environment are in some ways at odds with the desire on the Libraries' part to provide its users with the journals they most need and want. While it is tempting to argue that members at the consortium's extremes (the very large ones and the very small ones) would find themselves the most vulnerable, in fact there always seems to be sufficient diversity in the consortium to guarantee that every member on occasion finds its particular needs at odds with the consortium's goals. Reducing content through title cancellation (invoking OhioLINK's contractual "cost-for-content" clause) to stabilize the price of a particular publisher's package, regardless of how rational the criteria, ultimately gores someone's ox (Gatten and Sanville 2004). 
Big deals from consortia bring into sharp focus the differences in objectives between research libraries and the consortia. Consortia are focused on leasing or purchasing as much content at a good price as possible, and keeping an eye on the bottom line of each publisher's package deal. The beginning cost of these packages historically was negotiated based on the historic spending levels for print among the consortial members. Each year the percentage of increase for the package is examined carefully and challenged if it is above a certain level. Using this method to the extreme, a package of high quality journals with a higher percentage of price increase in a given year will be cut or reduced in size, while a mixed package of low and high quality journals with a smaller percentage of increase will be maintained. The end result is that lower quality journals will be kept in the collection while higher quality ones will be cut. Research libraries relinquish funds for these packages at the consortial level and effectively tie their hands in terms of limiting the costs of these deals by reducing titles. The titles contained in the large packages are not all highly valued by the faculty, whereas titles from smaller publishers and societies that are valued more highly cannot be funded from the research library's budget due to insufficient remaining funds. Researchers evaluate journals in their respective fields (or indeed, their subfields or specialties), and not in relation to titles in other disciplines published by the same publisher.

A major challenge confronts those trying to assess the value of a large package of journal titles from a major publisher. The quality and relative value of the journals in the package often varies widely, and a great deal of time is required to compile multiple data points for each title included in a package. From a faculty point of view, any meaningful evaluation must compare journals to others in the same discipline (or even more precisely) and not just to others in the publisher's package. The well-known ISI impact factors are not available for many or even most of the titles in a publisher package since that data set is limited to just under 7,000 titles. Especially at the consortial level when multiple types of libraries are involved, the question of assessing the value or worth to a large group of a big deal package is quite difficult.

\section{LITERATURE REVIEW}

The professional literature is full of ideas, proposals, and techniques to evaluate journals. The ISI impact factor is widely known and often criticized. Craig (2006) emphasizes that the impact factor is of real value only when used to compare journals within the same discipline that publish the same types of documents.

Rousseau (2002) provides an in-depth discussion of various journal evaluation methods. One interesting method is the popularity factor proposed by Yanovsky (1981), which measures whether a journal imports or exports knowledge. Other evaluation methods that have been used and discussed more recently include journal citation identity that measures the diversity of journals cited by authors, journal citation image that evaluates a journal by other journals that are co-cited with it, and internationalization that measures the breadth of appeal of a journal by examining the geographic locations of authors and cited authors (Bonnevie-Nebelong 2006). The journal diffusion factor method that is designed to measure the transdisciplinary reception of a journal is still under discussion and development (Frandsen, Rousseau, and Rowlands 2006). Although each of these methods has strengths and weaknesses, all of them require intensive work to produce results for a single journal title. They may perhaps be best used when evaluating a small number of titles in a given discipline, but do not seem practical to apply in a consortial environment with the assessment challenges presented by a large package of titles across 
disciplines.

The University of California Libraries has proposed that libraries move toward valuebased pricing and negotiations for big deal packages that require a different set of evaluative techniques (University of California Libraries' Collection Development Committee 2007). They provide four key elements that they determined to be relevant to establishing a value-based price for a large package. Those are a measure of scholarly value and impact, an index for changes in production costs, value-added contributions from member institutions such as editorial overhead, and the transaction efficiencies provided by a consortial deal. They also argue that reliance on historic print spending levels to determine appropriate costs for a big deal package is increasingly becoming a less valid method. Many journals exist in electronic format now that never had a print counterpart. The levels of historic print subscriptions also presumably have some correlation to the perceived value of the titles, and other ways of measuring value in the scholarly community are becoming available.

Ted Bergstrom and Preston McAfee (2006) have presented their work on a web site about journal cost-effectiveness as a way to evaluate the appropriate levels of pricing for journals within certain disciplines. Their work is based on the analysis of cost per article and cost per citation of each journal included in their data set, which is essentially the list of journals included in the ISI Journal Citation Reports. Cost data for each journal are compared to the median cost data for non-profit journals in the same discipline. If the cost data for a journal are near or below the median cost data for non-profit journals in the same discipline, the title is given a "good value" rating. Journals with cost data that do not compare favorably are given a "medium value" or "bad value" value rating depending on how much the cost data are above the median cost for non-profit journals. In an open letter to the scholarly community posted on their site, Bergstrom and McAfee plead with universities to respond to publishers about journals with a bad cost value rating.

Using mathematical modeling, Carl Bergstrom (2007) has developed a new approach to journal evaluation that measures the influence of a scholarly journal through citation patterns. The Eigenfactor, as he has named the resulting score, is based on a simple model of research in which readers follow chains of citations as they move from journal to journal. Ultimately, the influence of the journal is determined by the amount of time researchers spend with that journal. The Eigenfactor ranks journals in much the same way that Google's Page Rank algorithm ranks web sites and corrects for differences in citation patterns across disciplines. The Eigenfactor score is based on five years of citation data and the Eigenfactor database includes ratings for 115,000 titles, including newspapers, Ph.D. theses, and popular magazines. Bergstrom also has developed a comparable method of evaluation to the ISI impact factor and presents those data for a more limited set of titles.

\section{METHODOLOGY}

The authors selected the subfield of organic chemistry for an in-depth analysis of how various assessment techniques might shed light on journal content in a consortial environment. Other disciplines could be evaluated in the same way. The authors examined the organic chemistry titles included in the ISI Journal Citation Reports. The data set included 55 journal titles produced by nine non-profit publishers, 11 for-profit publishers, and two publishers for which profit status could not be determined. Four analysis factors were selected for the evaluation of each journal: faculty input, usage data, pricing value, and research value based on 
citation patterns.

Faculty opinion is critical to making educated and appropriate decisions about collection content. The Ohio State chemistry department faculty who specialized in the subfield of organic chemistry were asked to rate the 55 journals from the Journal Citation Reports list. Six faculty respondents selected a rating for each title in the categories of "must have," "nice to have," and "don't need."

Usage data during 2005 for the journals added another layer of insight. Twenty-eight of the titles were owned by the consortium and served to users from local servers. Seven titles were included in an aggregator database with a one year embargo provided through a consortial subscription. Seventeen titles were not owned by either the consortium or Ohio State. Three titles are freely accessible on the web. Usage data for the entire consortium were available for those titles owned and delivered locally from consortial servers. For the titles included in the consortially supplied aggregator database, an estimate of consortial usage data was calculated based on the usage data from Ohio State that were available to the authors. Based on the data obtained for the 17 titles owned and delivered locally by the consortium, usage from Ohio State on average accounted for $32 \%$ of all consortial use of the titles. Therefore, for the seven titles contained in the consortially leased aggregator database, total consortial use was estimated assuming that Ohio State's known use was $32 \%$ of the whole.

Most of the journals in the data set were included in Ted Bergstrom and Preston McAfee's work on journal pricing. Several were not, but the data were calculated for these few titles using the Bergstrom and McAfee method and sources. Accordingly, each journal was assigned a price value rating of "good," "medium," or "bad." Finally, in order to provide a rating of each journal based on scholarly influence as determined by citation patterns, an Eigenfactor percentile for each title was retrieved from Carl Bergstrom's work.

Based on Bergstrom and McAfee's three-tiered rating system of good, medium, and bad for pricing value, data from the other analyses similarly were grouped into three tiers. For the faculty input, for example, the tiers were "must have," "nice to have," and "don't need." Usage data were computed with the number of articles per journal title available for download to produce the average number of downloads per article in a journal title in 2005. The three tiers for usage data were less than .5 downloads per article, from .5 to .99 downloads per article, and one or more downloads per article. The Eigenfactor percentiles were grouped into the three tiers of less than $34 \%$, between 34 and $66 \%$, and over $66 \%$.

For each analysis factor, the journal titles were given a rating of zero, one, or two, depending on whether the rating was in the bottom, middle, or top category. For example, a journal title with a Bergstrom and McAfee pricing value of good received a rating of two, and an Eigenfactor percentile of $50 \%$ for the journal received a rating of one. When usage data were not available for a title because there was no consortial access, that analysis factor was simply omitted from the calculations for that title.

The four analysis factors were given equal weight in the evaluation. Research has shown that journals tend to establish reputations that endure even if their merit declines (Christenson and Sigelman 1985). The slow-to-change subjective measure of faculty opinion should work in concert with an objective measure of scholarly influence. A reasonable cost and the amount of use also are of critical import as a library's budget is limited and no library can afford to invest in resources that are not used very much by its community. Therefore, the four analysis factors of faculty opinion, research value, usage statistics, and pricing value were given equal importance in this study of a consortial environment. 


\section{RESULTS}

Table 1 provides data for the 55 titles in organic chemistry listed in the Journal Citation Reports. Usage data were not available if a title was not available to the consortium in 2005 . The maximum score for each analysis factor was two, so the total possible points were either six or eight depending upon the availability of usage data for a title.

TABLE 1. Organic Chemistry Titles Listed in the Journal Citation Reports

\begin{tabular}{|c|c|c|c|c|c|c|}
\hline Title & Publisher & $\begin{array}{l}\text { Faculty } \\
\text { Input } \\
\text { Score }\end{array}$ & $\begin{array}{l}\text { Eigenfactor } \\
\text { Research } \\
\text { Value Score }\end{array}$ & $\begin{array}{c}\text { Bergstrom } \\
\text { McAfee } \\
\text { Pricing } \\
\text { Score }\end{array}$ & $\begin{array}{l}\text { Usage } \\
\text { Data } \\
\text { Score }\end{array}$ & $\begin{array}{c}\text { Percent } \\
\text { of Total } \\
\text { Possible } \\
\text { Points }\end{array}$ \\
\hline $\begin{array}{l}\text { Advanced } \\
\text { Synthesis\&Catalysis }\end{array}$ & Wiley & 1 & 2 & 1 & 1 & $63 \%$ \\
\hline $\begin{array}{l}\text { Advances in } \\
\text { Carbohydrate Chemistry } \\
\text { and Biochemistry }\end{array}$ & $\begin{array}{l}\text { Elsevier } \\
\text { (Academic Press) }\end{array}$ & 1 & 0 & 0 & NA & $17 \%$ \\
\hline $\begin{array}{l}\text { Advances in } \\
\text { Hetereocyclic Chemistry }\end{array}$ & $\begin{array}{l}\text { Elsevier } \\
\text { (Academic Press) }\end{array}$ & 1 & 0 & 0 & NA & $17 \%$ \\
\hline $\begin{array}{l}\text { Advances in } \\
\text { Organometallic } \\
\text { Chemistry }\end{array}$ & $\begin{array}{l}\text { Elsevier } \\
\text { (Academic Press) }\end{array}$ & 1 & 1 & 0 & NA & $33 \%$ \\
\hline $\begin{array}{l}\text { Advances in Physical } \\
\text { Organic Chemistry }\end{array}$ & $\begin{array}{l}\text { Elsevier } \\
\text { (Academic Press) }\end{array}$ & 1 & 0 & 0 & NA & $17 \%$ \\
\hline Aldrichimica Acta & $\begin{array}{l}\text { Aldrich } \\
\text { Chemical Co. }\end{array}$ & 1 & 1 & 2 & NA & $67 \%$ \\
\hline Arkivoc & Arkat USA & 0 & 1 & 2 & NA & $50 \%$ \\
\hline Bioconjugate Chemistry & $\begin{array}{l}\text { American Chemical } \\
\text { Society }\end{array}$ & 2 & 2 & 2 & 0 & $75 \%$ \\
\hline Biomacromolecules & $\begin{array}{l}\text { American Chemical } \\
\text { Society }\end{array}$ & 1 & 2 & 2 & 1 & $75 \%$ \\
\hline $\begin{array}{l}\text { Bioorganic\&Medicinal } \\
\text { Chemistry Letters }\end{array}$ & Elsevier (Pergamon) & 2 & 2 & 2 & 1 & $88 \%$ \\
\hline $\begin{array}{l}\text { Bioorganic\&Medicinal } \\
\text { Chemistry }\end{array}$ & Elsevier (Pergamon) & 2 & 2 & 2 & 1 & $88 \%$ \\
\hline Bioorganic Chemistry & $\begin{array}{l}\text { Elsevier } \\
\text { (Academic Press) }\end{array}$ & 2 & 0 & 0 & 1 & $38 \%$ \\
\hline Carbohydrate Polymers & Elsevier & 0 & 2 & 0 & 0 & $25 \%$ \\
\hline Carbohydrate Research & Elsevier & 1 & 2 & 0 & 1 & $50 \%$ \\
\hline $\begin{array}{l}\text { Chemistry of Natural } \\
\text { Compounds }\end{array}$ & Springer & 1 & 0 & 0 & 0 & $13 \%$ \\
\hline $\begin{array}{l}\text { Chinese Journal of } \\
\text { Organic Chemistry }\end{array}$ & Science Press & 0 & 0 & 2 & NA & $33 \%$ \\
\hline Chirality & Wiley & 0 & 2 & 0 & 0 & $25 \%$ \\
\hline $\begin{array}{l}\text { Current Organic } \\
\text { Chemistry }\end{array}$ & Bentham Science & 0 & 2 & 0 & 1 & $38 \%$ \\
\hline $\begin{array}{l}\text { Current Organic } \\
\text { Synthesis }\end{array}$ & Bentham Science & 0 & 0 & 0 & 0 & $0 \%$ \\
\hline $\begin{array}{l}\text { European Journal of } \\
\text { Organic Chemistry }\end{array}$ & Wiley & 2 & 2 & 1 & 1 & $75 \%$ \\
\hline
\end{tabular}




\begin{tabular}{|c|c|c|c|c|c|c|}
\hline Hetereocycles & Elsevier (Pergamon) & 2 & 2 & 0 & NA & $67 \%$ \\
\hline $\begin{array}{l}\text { Hetereocyclic } \\
\text { Communications }\end{array}$ & Freund & 0 & 0 & 1 & NA & $17 \%$ \\
\hline $\begin{array}{l}\text { Indian Journal of } \\
\text { Chemistry Section B- } \\
\text { Organic } \\
\text { Chemistry Including } \\
\text { Medicinal Chemistry }\end{array}$ & $\begin{array}{l}\text { Natl Inst Science } \\
\text { Communication }\end{array}$ & 1 & 1 & 2 & NA & $67 \%$ \\
\hline $\begin{array}{l}\text { Indian Journal of } \\
\text { Hetereocyclic Chemistry }\end{array}$ & Dr. RS Varma & 0 & 0 & 2 & NA & $33 \%$ \\
\hline $\begin{array}{l}\text { Journal of Carbohydrate } \\
\text { Chemistry }\end{array}$ & Taylor\&Francis & 2 & 1 & 0 & 1 & $50 \%$ \\
\hline $\begin{array}{l}\text { Journal of Fluorine } \\
\text { Chemistry }\end{array}$ & Elsevier & 0 & 2 & 0 & 0 & $25 \%$ \\
\hline $\begin{array}{l}\text { Journal of Hetereocyclic } \\
\text { Chemistry }\end{array}$ & Hetero Corporation & 2 & 2 & 2 & NA & $100 \%$ \\
\hline $\begin{array}{l}\text { Journal of Mass } \\
\text { Spectrometry }\end{array}$ & Wiley & 2 & 2 & 0 & 2 & $75 \%$ \\
\hline $\begin{array}{l}\text { Journal of Organic } \\
\text { Chemistry }\end{array}$ & $\begin{array}{l}\text { American Chemical } \\
\text { Society }\end{array}$ & 2 & 2 & 2 & 0 & $75 \%$ \\
\hline $\begin{array}{l}\text { Journal of } \\
\text { Organometallic } \\
\text { Chemistry }\end{array}$ & Elsevier & 2 & 2 & 0 & 0 & $50 \%$ \\
\hline $\begin{array}{l}\text { Journal of Physical } \\
\text { Organic Chemistry }\end{array}$ & Wiley & 2 & 1 & 0 & 0 & $38 \%$ \\
\hline $\begin{array}{l}\text { Journal of Synthetic } \\
\text { Organic Chemistry Japan }\end{array}$ & $\begin{array}{l}\text { Soc Synthetic } \\
\text { Organic Chemistry } \\
\text { Japan }\end{array}$ & 1 & 1 & 2 & NA & $67 \%$ \\
\hline $\begin{array}{l}\text { Khimiya } \\
\text { Geterotsiklicheskikh } \\
\text { Soedinenii }\end{array}$ & $\begin{array}{l}\text { Khimiya } \\
\text { Geterotsiklicheskikh } \\
\text { Soedineniya }\end{array}$ & 0 & 0 & 0 & NA & $0 \%$ \\
\hline $\begin{array}{l}\text { Letters in Organic } \\
\text { Chemistry }\end{array}$ & Bentham Science & 0 & 0 & 0 & 0 & $0 \%$ \\
\hline $\begin{array}{l}\text { Main Group Metal } \\
\text { Chemistry }\end{array}$ & Freund & 0 & 1 & 0 & NA & $17 \%$ \\
\hline $\begin{array}{l}\text { Mini-Reviews in Organic } \\
\text { Chemistry }\end{array}$ & Bentham Science & 1 & 0 & 0 & 0 & $13 \%$ \\
\hline Molecules & $\begin{array}{l}\text { Molecular Diversity } \\
\text { Preservation } \\
\text { International }\end{array}$ & 0 & 1 & 0 & NA & $17 \%$ \\
\hline Natural Product Reports & $\begin{array}{l}\text { Royal Society of } \\
\text { Chemistry }\end{array}$ & 2 & 2 & 0 & 2 & $75 \%$ \\
\hline $\begin{array}{l}\text { Organic\&Biomolecular } \\
\text { Chemistry }\end{array}$ & $\begin{array}{l}\text { Royal Society of } \\
\text { Chemistry }\end{array}$ & 2 & 2 & 0 & 1 & $63 \%$ \\
\hline Organic Letters & $\begin{array}{l}\text { American Chemical } \\
\text { Society }\end{array}$ & 2 & 2 & 2 & 1 & $88 \%$ \\
\hline $\begin{array}{l}\text { Organic Preparations } \\
\text { and Procedures } \\
\text { International }\end{array}$ & $\begin{array}{l}\text { Organic Prep } \\
\text { Procedures }\end{array}$ & 1 & 1 & 1 & NA & $50 \%$ \\
\hline $\begin{array}{l}\text { Organic Process } \\
\text { Research\&Development }\end{array}$ & $\begin{array}{l}\text { American Chemical } \\
\text { Society }\end{array}$ & 1 & 1 & 1 & 0 & $38 \%$ \\
\hline Organometallics & $\begin{array}{l}\text { American Chemical } \\
\text { Society }\end{array}$ & 2 & 2 & 2 & 0 & $75 \%$ \\
\hline Petroleum Chemistry & Interperiodica & 1 & 0 & 0 & NA & $17 \%$ \\
\hline $\begin{array}{l}\text { Polycyclic Aromatic } \\
\text { Compounds }\end{array}$ & Taylor\&Francis & 0 & 0 & 0 & 2 & $25 \%$ \\
\hline $\begin{array}{l}\text { Russian Journal of } \\
\text { Bioorganic Chemistry }\end{array}$ & Nauka/Interperiodica & 1 & 0 & 0 & 0 & $13 \%$ \\
\hline
\end{tabular}




\begin{tabular}{|c|c|c|c|c|c|c|}
\hline $\begin{array}{l}\text { Russian Journal of } \\
\text { Organic Chemistry }\end{array}$ & Nauka/Interperiodica & 1 & 1 & 0 & 0 & $25 \%$ \\
\hline Synlett & Thieme & 2 & 2 & 2 & 2 & $100 \%$ \\
\hline Synthesis-Stuttgart & Thieme & 2 & 2 & 2 & 2 & $100 \%$ \\
\hline $\begin{array}{l}\text { Synthetic } \\
\text { Communications }\end{array}$ & Taylor\&Francis & 2 & 2 & 1 & 0 & $63 \%$ \\
\hline Tetrahedron & Elsevier (Pergamon) & 2 & 2 & 0 & 1 & $63 \%$ \\
\hline Tetrahedron Letters & Elsevier (Pergamon) & 2 & 2 & 2 & 1 & $88 \%$ \\
\hline Tetrahedron-Asymmetry & Elsevier (Pergamon) & 2 & 2 & 2 & 0 & $75 \%$ \\
\hline Topics in Stereochemistry & Wiley & 1 & 0 & 0 & NA & $17 \%$ \\
\hline $\begin{array}{l}\text { Zeitschrift fur } \\
\text { Naturforschung Section } \\
\text { B-A } \\
\text { Journal of Chemical } \\
\text { Sciences }\end{array}$ & VerlagZNaturforsch & 1 & 1 & 1 & NA & $50 \%$ \\
\hline
\end{tabular}

\section{DISCUSSION}

The analysis results revealed some clear differences among the organic chemistry journal publishers. The two titles published by Thieme, for example, garnered top marks from all for analysis factors for a total overall score of $100 \%$. Five of the six titles published by the American Chemical Society received scores of $75 \%$ or higher. Elsevier titles from the former Pergamon publishing house fared better than Elsevier titles from the former Academic Press imprint. Other large publishers such as Wiley and Taylor \& Francis received mixed results in this sample of organic chemistry titles.

Occasionally usage data scores seem low for prominent titles. Generally this phenomenon occurs when a journal such as the Journal of Organic Chemistry from the American Chemical Society publishes a large number of articles, only a portion of which are cited frequently. The usage data scores are based on the average download per available article and are impacted significantly by the quantity of articles produced.

No journal that received top scores from the faculty had an overall score lower than $38 \%$. Of the 55 titles, 33 were either rated in the highest category by faculty or had at least a total score of $38 \%$. Five of the 33 titles were included on the list only because of high scores from the faculty, as their scores in the remaining factors were not high enough to produce a total score of at least $38 \%$. Of the 33 titles scoring $38 \%$ or above, the consortium supplies all but eight of them. Three of the eight are freely accessible, and the remaining five are not owned or leased by OhioLINK or Ohio State. Of the remaining 22 titles that fell below an overall score of $38 \%$, the consortium provides access to eight of those titles.

Two of the 22 titles that did not obtain an overall score of at least $38 \%$ were published by non-profit publishers, and the profit status of another could not be determined. Thirteen of the 33 titles with an overall score of $38 \%$ or higher were published by non-profit publishers. The nonprofit publishers overall achieved higher scores than the for-profit publishers. Based on microeconomics and statistical theory, Carl and Ted Bergstrom argue that non-profit publisher site licenses are more beneficial to the user community than site licenses from for-profit publishers (Bergstrom and Bergstrom 2004). The data presented here certainly suggest that nonprofit site licenses should be regarded more favorably for additional reasons.

Of the eight titles provided by the consortium that fell below $38 \%$ for an overall score, four titles are included in big deal packages and the other four are available through a consortially leased aggregator database with a one year embargo. The analysis suggests that the four titles in the big 
deal packages probably could be cancelled or some deal arranged for their purchase at a price that represents the value they hold to the consortium. The current 2007 prices for a single institutional subscription to these four titles as listed on the publishers' web sites total $\$ 13,989$. The two titles in the consortially acquired aggregator database probably do not need to be acquired in any other manner. In contrast, the three titles not provided by the consortium that received total scores between 50 and $67 \%$ have a combined 2007 annual institutional subscription cost of $\$ 1,796$. All three titles are from small nonprofit publishers. Even if it is not cost-effective or feasible for the consortium to acquire content from small publishers, a reduction in the big deal charges passed along to the members could enable the members to purchase content from smaller publishers on their own that is more desirable.

In a separate research project at The Ohio State University Libraries, Sarah Murphy (Murphy n.d.) has analyzed science faculty publication and citation patterns that included the faculty in organic chemistry. Fifteen organic chemistry journals were cited 10 or more times in publications by OSU organic chemistry faculty from 2003 to 2005. Of these 15 journals, only one title fell below an overall score of $50 \%$ in the current analysis. There is a strong correlation between the organic chemistry journals frequently cited from 2003 to 2005 by Ohio State organic chemistry faculty and overall scores of $50 \%$ or higher.

Data from Murphy's research also show that OSU organic chemistry faculty authored 49 articles published in 14 journals from 2003 to 2005, and only three articles (6\% of the total) were in journals with an overall score below $38 \%$. The overlap of the OSU organic chemistry faculty publication journals and their cited journals includes the eight journals listed below with their overall scores.

\section{Bioorganic and Medicinal Chemistry 88\% (Elsevier) \\ 2. Journal of Organic Chemistry $75 \%$ (ACS) \\ 3. Organic Letters $88 \%$ (ACS) \\ 4. Organometallics $63 \%$ (ACS) \\ 5. Synlett $100 \%$ (Thieme) \\ 6. Tetrahedron $63 \%$ (Elsevier) \\ 7. Tetrahedron Letters $88 \%$ (Elsevier) \\ 8. Tetrahedron-Asymmetry $75 \%$ (Elsevier)}

The overall scores in the analysis are high for the essential journals cited by and containing publications by OSU authors. Clearly, these titles are sound investments. In general, those journal titles with overall scores of $50 \%$ or higher are essential. Journals with overall scores of $38-49 \%$ should be considered carefully, and the value to the consortium of those journals with scores below 38\% is unclear.

Murphy's data also show that of the top 100 journals in all disciplines cited by OSU organic chemistry faculty in from 2003 to 2005, the consortium has supplied all except 18 of them. Many of these journals are not specifically related to organic chemistry. The consortium is doing well at supplying needed journals for organic chemistry faculty, but needs to continue to seek ways of reducing expenditures for journals of little value to the consortium in big deal packages. If Ohio State were evaluating the results of this analysis with the intent of canceling some less desirable titles in order to pay for more desirable ones, the path to that goal would be clear.

Douglas and Roth (2006) take much the same position as they plead the cause of the small scholarly society publisher in the field of chemistry (Douglas and Roth 2006). The big deals are not necessarily bad, but the price for them must be right for the value the content holds for the consortium. Roth (2006) also makes the case that librarians need to demand objective evaluation criteria in order to establish the value and quality of journals for their community. The 
analysis of the four factors discussed above attempts to combine multiple objective data points with the subjective contributions of faculty.

\section{CONCLUSION}

A combined analysis of the four factors leads to a clearer picture of journals in a particular discipline. The sample used in this study was small, but the results of the study suggest that the same techniques could be used to evaluate a publisher's package for content and value since the Eigenfactor scores are comparable among disciplines. The objective data gathering and number crunching exercises would be time consuming, but doable and worth the time spent if hundreds of thousands or even millions of dollars were at stake. The difficult part would be distributing publisher titles to faculty by discipline for their evaluation and persuading faculty to take the time to provide input into the process. Ohio State alone has 4,500 faculty members. Obtaining faculty input on a consortial level would be a complex task, but still could be done using appropriate sampling techniques. Without faculty input, though, any analysis will be incomplete. The results of the analysis could be used in price negotiations with publishers to bring big deal costs in line with the value the package represents for the consortium as suggested by the University of California Libraries. The study also highlights the fact that at least in the field of organic chemistry, non-profit publishers tend to produce journals of overall better value.

Analyzing a publisher package of journals is difficult, especially at a consortial level. Big deals with large publishers often lead to a consortium paying for some titles that are not of great interest to faculty. Faculty often mention this point when told that their institution does not have enough funds to support subscriptions they request. Faculty opinion provides balance to objective measures of journals, and is an essential component of effective collection evaluation.

The library manager's work is not complete, however, until information about collection decisions is shared with all stakeholders. Difficult decisions are easier to make, announce, and live with when all stakeholders openly share information. Library managers can expect that faculty distraught over the loss of their favorite journal will be indifferent to the Eigenfactor and other data. Likewise, library managers from other consortium members will certainly bring their own data sets and battle scars to the decision-making table.

Additional data sets, a few fresh wounds, and the analytical and anecdotal know-how of other library managers and faculty are indeed valuable assets. They make the proverbial "decision-making table" congested but ebullient with ideas. They can save colleagues from the twin evils of parochialism and tunnel vision. They alert institutional library managers, often confounded by the consortium's intricate conventions and seemingly unruly administrative process, of the association's original purposes and the complexities of bringing them to fruition. On some occasions information sharing builds consensus, generates new ideas, suggests policy alterations, and even brokers profitable backroom deals. The yearly fall meeting, for example, of OhioLINK's chemistry subject specialists offers a sober reminder that we are all in this together, and that even if our favorite ox has been stabbed, it is not personal but strictly business.

The "business" is educating faculty producers/consumers in the economic realities of journal price increases: (1) no additional money in the budget buys no additional content; and (2) a flat budget can only buy less content. Library managers must be prepared with hard, accurate facts to counter the faculty's sincere cries of pain when they hear this. For example, when faculty object to the use of particular data sets to determine what is kept or cancelled and argue instead for the use of ISI impact factors, it is imperative that the library manager has done sufficient 
homework to be able to advise the faculty of the limitations of the ISI data-that the ISI data are not available for many or even most of the titles in a publisher package since that data set is limited to just under 7,000 titles. Repeating this to faculty is part of the educational process that is the basis of changing scholarly communication. Following up this response with a faculty survey, like the one described above, to get supplemental data in the form of faculty input essentially demonstrates the library manager's attentiveness to faculty concerns while enlisting the faculty in the search for a satisfactory solution. Yes, it is more work for both the library manager and faculty. No one said changing scholarly communication would be easy.

Engaging members of the OhioLINK consortium, on the other hand, is a bit like lobbying and mostly happens in monthly collection management meetings as well as in ad hoc e-mail exchanges. An important realization is that only some of the battles can be won. Not all members of the consortium aspire to changing the scholarly communication process. Sometimes their institutions do allocate more money. It is also important to remember a whole set of consortial truisms: that consortial life is a compromise, that a consortium is only as strong as its members, and that the playing field is never level. Some chemistry faculty, for example, can protest louder than others. A diverse membership is both OhioLINK's weakness and its strength. As its "strongest" member (however that might be measured), The Ohio State University Libraries often finds itself in the position of the 800-pound gorilla with the most to gain and the most to lose in any situation. As much as Ohio State is committed to changing the scholarly communication process, it is also committed to OhioLINK's success. Giving faculty author concerns a consortial hearing is part of changing the scholarly communication process. Like Eigenfactor, impact factor, cost-per-download, usage, and other data, faculty input has a place in consortial decision-making despite the fact that the outcome of any situation might seem to have been predetermined by simple economics. The situation is one of evolution, not revolution.

Few discussions are more polemic than those related to making versus breaking the "Big

Deal." As noted above, the purchasing of a publisher's journal list, on the one hand, gets the most content for the greatest numbers for the least money, while on the other hand, ties up the same money in specific titles that none of the consortium's individual members would have ever considered buying. When not all titles are equally valued, no matter how that value is measured, everyone seems to have a title next in line to be cut. OhioLINK has yet to come up with a strategy that appeals to publishers to add wanted content while excluding unwanted content and maintaining the same price. This strategy may well be the Holy Grail of the quest that is any consortium-publisher negotiation. Discovering it will signal the changing of how faculty producers/consumers, library managers, and publishers engage in scholarly communication.

\section{REFERENCES}

Bergstrom, Carl. 2007. Eigenfactor.org: Ranking and mapping scientific knowledge. http://www.eigenfactor.org/ (accessed July 13, 2007).

Bergstrom, Carl, and Ted Bergstrom. 2004. The costs and benefits of library site licenses to academic journals. Proceedings of the National Academy of Sciences 101(3): 897-902.

Bergstrom, Ted, and Preston McAfee. 2006. Journal cost-effectiveness 2005-06 beta. http://www.journalprices.com (accessed July 13, 2007).

Bonnevie-Nebelong, Ellen. 2006. Methods for journal evaluation: Journal citation identity, journal citation image and internationalization. Scientometrics 66 (2): 411-424.

Christenson, James A., and Lee Sigelman. 1985. Accrediting knowledge: Journal stature and citation impact in social science. Social Science Quarterly 66 (4): 964-975.

Craig, Iain. 2006. The pros and woes of the impact factor, librarynews 33 (December): 5. http://www.blackwellpublishing.com/librarians/newsletter_pdf/librarynews-No33.pdf (accessed July 13,2007). 
Douglas, Kimberly, and Dana Roth. 2006. Looming threats to society journals. Chemical \& Engineering News 84 (47): 82-84.

Frandsen, Tove Faber, Ronald Rousseasu, and Ian Rowlands. 2006. Diffusion factors. Journal of Documentation 62 (1): 58-72.

Gatten, Jeffrey N., and Tom Sanville. 2004. An orderly retreat from the big deal: Is it possible for consortia? D-Lib Magazine 10 (10). http://www.dlib.org/dlib/october04/gatten/10gatten.html (accessed July 13, 2007).

Murphy, Sarah, n.d. A comparison of the effects of portfolio purchasing on scientific subject collections. College and Research Libraries. Forthcoming.

Roth, Dana. 2006. Value and quality measures for chemistry research journals. Paper presented at Special Libraries Association Annual Conference, June 11-14, 2006. http://resolver.caltech.edU/CaltechLIB:2006.003 (accessed July 13, 2007).

Rousseau, Ronald. 2002. Journal evaluation: Technical and practical issues. Library Trends 50 (3): 418-439.

University of California Libraries' Collection Development Committee. 2007. The promise of value-based journal prices and negotiation: A UC report and view forward. http://libraries.universityofcalifornia.edu/cdc/valuebasedprices.pdf (accessed July 13,2007).

Yanovsky, V. I. 1981. Citation analysis significance of scientific journals. Scientometrics 3 (3): 223-233. 